\title{
Nicastrin Is Required for Assembly of Presenilin $/ \gamma$-Secretase Complexes to Mediate Notch Signaling and for Processing and Trafficking of $\beta$-Amyloid Precursor Protein in Mammals
}

\author{
Tong Li, ${ }^{1}$ Guojun Ma, ${ }^{1,2}$ Huaibin Cai, ${ }^{1}$ Donald L. Price, ${ }^{1,2,3}$ and Philip C. Wong ${ }^{1,2}$ \\ Departments of ${ }^{1}$ Pathology, ${ }^{2}$ Neuroscience, and ${ }^{3}$ Neurology, The Johns Hopkins University School of Medicine, Baltimore, Maryland 21205
}

Recent studies indicate that nicastrin (NCT) and presenilins form functional components of a multimeric $\gamma$-secretase complex required for the regulated intramembraneous proteolysis of Notch and $\beta$-amyloid $(\mathrm{A} \beta)$ precursor protein (APP). To determine whether nicastrin is required for proteolytic processing of Notch and APP in mammals and the role of nicastrin in presenilin $/ \gamma$-secretase complex assembly, we generated nicastrin-deficient $\left(\mathrm{NCT}^{-/-}\right)$mice and derived fibroblasts from $\mathrm{NCT}^{-/-}$embryos. Nicastrin-null embryos died by embryonic day 10.5 and exhibited several patterning defects, including abnormal somite segmentation, phenotypes that are reminiscent of embryos lacking Notch 1 or both presenilins. Importantly, secretion of A $\beta$ peptides is abolished in $N C T^{-1-}$ fibroblasts, whereas it is reduced by $\sim 50 \%$ in $\mathrm{NCT}^{+-}$cells; the failure to generate $\mathrm{A} \beta$ peptides in $\mathrm{NCT}^{-/-}$cells is accompanied by destabilization of the presenilin $/ \gamma$-secretase complex and accumulation of APP-C-terminal fragments. Moreover, APP trafficking analysis in $\mathrm{NCT}^{-/-}$fibroblasts revealed a significant delay in the rate of APP reinternalization compared with that of control cells. Together, these results establish that nicastrin is an essential component of the multimeric $\gamma$-secretase complex in mammals required for both $\gamma$-secretase activity and APP trafficking and suggest that nicastrin may be a valuable therapeutic target for Alzheimer's disease.

Key words: nicastrin knock-out mice; nicastrin-deficient fibroblasts; presenilin/ $\gamma$-secretase complex; Notch signaling; APP processing and trafficking; Alzheimer's disease

\section{Introduction}

Alzheimer's disease (AD), a progressive neurodegenerative disorder of the elderly, is characterized by dementia, the deposition of $\beta$-amyloid (A $\beta)$, and the presence of neurofibrillary tangles in the hippocampus and cortex (Price and Sisodia, 1998). Endoproteolytic cleavages of $\beta$-amyloid precursor protein (APP) by the activities of $\beta$ - and $\gamma$-secretase result in the generation of $\mathrm{A} \beta$ peptides that are believed to be neurotoxic (Hardy and Selkoe, 2002; Wong et al., 2002). The presenilins (PSs), which when mutated cause autosomal dominant AD (Sisodia and GeorgeHyslop, 2002), are essential for the regulated intramembraneous proteolysis of a variety of transmembrane proteins, including APP (De Strooper et al., 1998; Naruse et al., 1998), Notch (De Strooper et al., 1999; Saxena et al., 2001), ErbB4 (Ni et al., 2001), and E-cadherin (Marambaud et al., 2002). Although it is not completely clear whether PSs themselves act as aspartal proteases (Wolfe et al., 1999; Esler et al., 2000; Li et al., 2000a,b), function as cofactors critical for the activity of $\gamma$-secretase, or exert their influence by playing a role in the trafficking of substrates (Naruse et al., 1998; Kim et al., 2001), recent studies support the view that presenilins play a dual role in both the processing by $\gamma$-secretase and the trafficking of substrates (Kaether et al., 2002). An emerg-

\footnotetext{
Received Dec. 11, 2002; revised Feb. 10, 2003; accepted Feb. 11, 2003.

This work was supported by grants from the National Institutes of Health (NS41438 and NS45150), the Rotary CART Fund, Adler Foundation, and Bristol-Myers Squibb Foundation. We thank Y. Wang, M. Estevez, E. Corpus, J. Peck, F. Davenport, E. Ruch, and G. Cristostomo for technical support.

Correspondence should be addressed to Dr. Philip C. Wong, Department of Pathology, The Johns Hopkins University School of Medicine, 558 Ross Research Building, 720 Rutland Avenue, Baltimore, MD 21205-2196. E-mail: wong@jhmi.edu.

Copyright $\odot 2003$ Society for Neuroscience $\quad 0270-6474 / 03 / 233272-06 \$ 15.00 / 0$
}

ing view is that PSs form high molecular weight complexes with several other transmembrane proteins critical for the generation of functional $\gamma$-secretase complexes.

One important member of the $\gamma$-secretase complex is nicastrin (NCT), a type I transmembrane glycoprotein, which forms high molecular weight complexes with presenilins ( $\mathrm{Yu}$ et al., 2000) and binds to the membrane-tethered form of Notch1 (Chen et al., 2001). Recent studies have indicated that nicastrin is required for Notch signaling and APP processing (Yu et al., 2000; Chung and Struhl, 2001; Edbauer et al., 2002; Hu et al., 2002; Lopez-Schier and St Johnston, 2002). Studies in Drosophila have shown that nicastrin may function to stabilize PSs and appears to be critical for the trafficking of PSs to the cell surface. Likewise, PS is required for the maturation and cell surface accumulation of nicastrin (Edbauer et al., 2002; Kaether et al., 2002; Leem et al., 2002). These results have suggested that nicastrin and PSs form functional components of a multimeric complex required for the intramembraneous proteolysis of both Notch and APP. To determine the physiological role of nicastrin in mammals and to clarify the mechanism whereby nicastrin facilitates the assembly of PSs into a functional $\gamma$-secretase complex, we generated and analyzed nicastrin-deficient $\left(N C T^{-/-}\right)$mice and $N C T^{-/-}$fibroblasts. $\mathrm{NCT}^{-/-}$embryos show phenotypes that resemble those of Notch1 $1^{-/-}$(Swiatek et al., 1994; Conlon et al., 1995; Huppert et al., 2000) or $P S^{-1-}$ (Donoviel et al., 1999; Herreman et al., 1999) embryos. Significantly, secretion of $\mathrm{A} \beta$ peptides is abolished in $\mathrm{NCT}^{-/-}$fibroblasts, whereas it is reduced by $\sim 50 \%$ in $\mathrm{NCT}^{+/-}$ cells. In addition, cell surface reinternalization of APP is markedly delayed in $\mathrm{NCT}^{-/-}$fibroblasts. Our data support the view that nicastrin is an essential component of the $\gamma$-secretase com- 
A

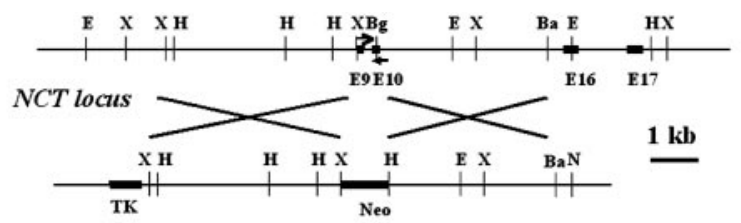

Targeting Vector
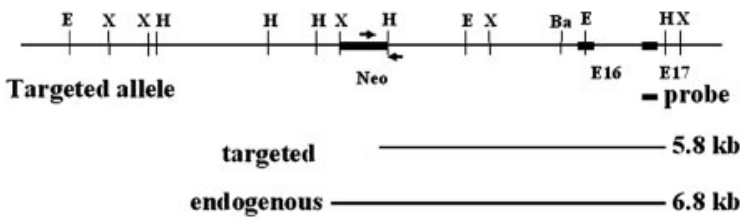

B

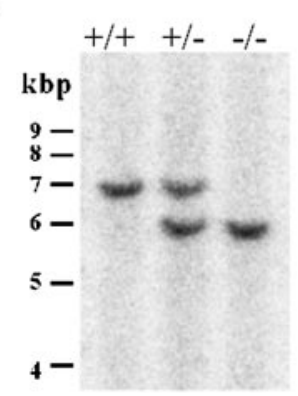

C

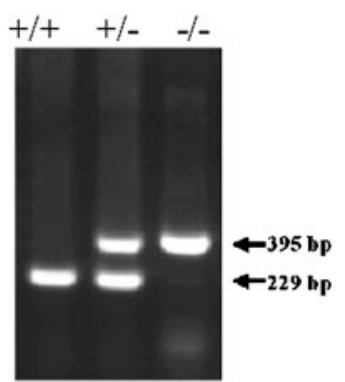

Figure 1. Targeted disruption of nicastrin gene by homologous recombination. A, Maps of the wild-type NCT locus, the targeting vector, and the disrupted NCT allele. Exon 9 (E9) and exon 10 are indicated by black boxes. The targeting vector shows the replacement of the exon 9, part of exon 10, and the intron 9 sequences by neomycin gene ( $\mathrm{NeO}$ ). Arrows indicate the sites within the targeted and the wild-type alleles from which PCR primers were chosen for genotyping. Lines below denote expected sizes for Hindlll-digested fragments detected by a 3 '-flanking probe (a 0.3 kb PCR fragment; black bar) from targeted and endogenous NCT alleles. $B$, Analysis of genomic DNA from mouse embryos by Southern blot. The Hindlll fragment detected for wild-type $(6.8 \mathrm{~kb})$ and targeted $(5.8 \mathrm{~kb})$ NCT alleles with the $3^{\prime}$ probe are indicated. C, PCR analysis of DNA extracted from embryos using primers indicated in Figure $1 A$. The 395 or $229 \mathrm{bp}$ fragment is specific to the targeted or endogenous $N C T$ allele, respectively. $E, E C o R I ; X, X b a l ; B G$, Bg/ll; BA, BamHI; N, Notl; TK, thymidine kinase; +/+, wild type; +/-, Nicastrin heterozygous; $-/-$, Nicastrin knock-out.

plex that controls PS assembly and APP trafficking in mammals and, as such, represents a potential therapeutic target for the treatment of Alzheimer's disease.

\section{Materials and Methods}

Generation and analysis of $\mathrm{NCT}^{-/-}$mice. The NCT gene, isolated from a murine genomic 129/Sv library (Stratagene, La Jolla, CA) using a murine NCT CDNA probe was characterized by DNA blotting and sequencing. In the NCT targeting vector, a $0.5 \mathrm{~kb}$ fragment containing exon 9 , intron 9 , and part of exon 10 of the NCT gene was replaced with a neomycinresistant $(\mathrm{Neo})$ gene. The linearized NCT targeting vector was electroporated into 129/suj embryonic stem (ES) cells, and targeted clones were selected by DNA blot analysis. Four independent targeted clones were injected into C57BL/6 blastocysts to generate NCT chimeric mice. Mating of chimeric mice to $\mathrm{C} 57 \mathrm{BL} / 6$ mice produced offspring bearing one inactivated $\mathrm{NCT}$ allele $\left(\mathrm{NCT}^{+/-}\right.$mice) and intercrosses of $\mathrm{NCT}^{+/-}$mice generated $\mathrm{NCT}^{-/-}$mice. DNA extracted from tail clips of mice or yolk

Table 1. Progenies of crosses of $\mathrm{NCT}^{+/-}$mice

\begin{tabular}{llllrl}
\hline Age & No. of litters & Total no. of pups & $N C T^{+/+}$ & $N C T^{+/-}$ & $N C T^{-/-}$ \\
\hline E8-E8.5 & 10 & 80 & 19 & 43 & 18 \\
E9-E9.5 & 6 & 58 & 15 & 28 & 15 \\
E10-E10.5 & 3 & 19 & 6 & 9 & 4 \\
E11-E14 & 9 & 55 & 19 & 36 & 0 \\
Adult & 9 & 56 & 21 & 35 & 0 \\
\hline
\end{tabular}

CTES, tre (NCT-3925, 1:2000) or previously characterized antisera specific for PS1 (Thinakaran et al., 1996) (PS1-NTF, 1:5000; PS1-loop, 1:2500). Antiserum 7523 against the $\mathrm{N}$ terminus of $\beta$-secretase (BACE1) was as described previously (Cai et al., 2001). APP and APP-CTFs were detected using antibodies CT-15 (Chemicon, Temecula, CA). Monoclonal antibody against actin was purchased from Chemicon. Antibody against APP $\mathrm{N}$-terminal P2-1 was from BioSource International (Camarillo, CA).

$A \beta$ assays. APP recombinant adenovirus was constructed as described previously (Cai et al., 2001). To assay the APP processing, fibroblasts were infected with $5 \times 10^{6}$ plaque-forming units of adenovirus expressing human APPswe for $24-48 \mathrm{hr}$. A $\beta_{1-42}$ and $\mathrm{A} \beta_{1-40}$ levels from culture supernatants of cells were measured using a quantitative sandwich ELISA kit (BioSource International) that specifically detects human $\mathrm{A} \beta$.

Mass spectrometric analysis. The $\beta$-amyloid peptides in cultured medium were captured with 6E10 monoclonal antibody on preactivated PS20 ProteinChip (Ciphergen Biosystems, Palo Alto, CA). ProteinChip array was analyzed by surfaceenhanced laser desorption/ionization time-offlight mass spectrometry (MS) in the presence of 
$\alpha$-cyano-4-hydroxy cinnamic acid (CHCA) matrix solution (Ciphergen Biosystems). External standards were used for calibration.

\section{Results}

Targeted inactivation of mouse nicastrin gene

To determine whether nicastrin is required for presenilin-mediated Notch signaling and APP processing in mammals and to examine the mechanism whereby nicastrin facilitates the assembly of the $\gamma$-secretase complex, we began by examining the functional consequence of ablating the NCT gene in mice. We used a homologous recombination strategy in ES cells to inactivate the mouse NCT gene. We screened a mouse genomic $129 / \mathrm{Sv}$ library with a mouse NCT cDNA as probe. To generate the NCT targeting vector, a $0.5 \mathrm{~kb}$ fragment containing exon 9 , intron 9 , and part of exon 10 of the NCT gene was replaced with a neomycin-resistant gene (Fig. 1A). 129/suj ES cells were transfected with the linearized NCT targeting vector, and 16 clones (of 200 screened) were targeted at the NCT locus. Of the 16 targeted clones, 4 ES cell clones with a targeted nicastrin allele $\left(\mathrm{NCT}^{+/-}\right)$were injected into $\mathrm{C} 57 \mathrm{BL} / 6$ blastocysts to generate NCT-chimeric mice. Mating of chimeric mice to $\mathrm{C} 57 \mathrm{BL} / 6$ mice produced offspring bearing one inactivated NCT allele $\left(\mathrm{NCT}^{+/-}\right.$mice), and intercrosses of $\mathrm{NCT}^{+/-}$mice produced $\mathrm{NCT} \mathrm{T}^{-/-}$mice (Fig. $1 B, C$ ). Genotypic analysis of postnatal progeny from intercrosses of $\mathrm{NCT}^{+/-}$ mice revealed only $\mathrm{NCT}^{+/+}$and $\mathrm{NCT}^{+/-}$ pups, an observation consistent with the concept that deletion of nicastrin may lead to embryonic lethality. To determine the age and stage at which embryos die, we collected embryos from E8 to E14. Whereas $\mathrm{NCT}^{+/+}$and $\mathrm{NCT}^{+/-}$embryos were identified at these time points, no $\mathrm{NCT}^{-/-}$embryos were recovered beyond E10.5 (Table 1).

\section{Notch signaling abnormalities in \\ $\mathrm{NCT}^{-/-}$mice}

To determine whether the nicastrin-null phenotype resembles that of the PS1+PS2 double knock-out (Donoviel et al., 1999; Herreman et al., 1999) or Notch1-null (Swiatek et al., 1994; Conlon et al., 1995; Huppert et al., 2000) embryos, we undertook a series of morphological studies to characterize the embryonic phenotypes of $\mathrm{NCT}^{-/-}$embryos. The development of $\mathrm{NCT}^{-/-}$embryos was dramatically retarded by E9.5 compared with heterozygous or wild-type littermates (Fig. $2 A$ ). Notably, $N C T^{-/-}$embryos exhibited defects in the development of caudal parts of the embryo and in somite segmentation (Fig. 2B); in addition, there were
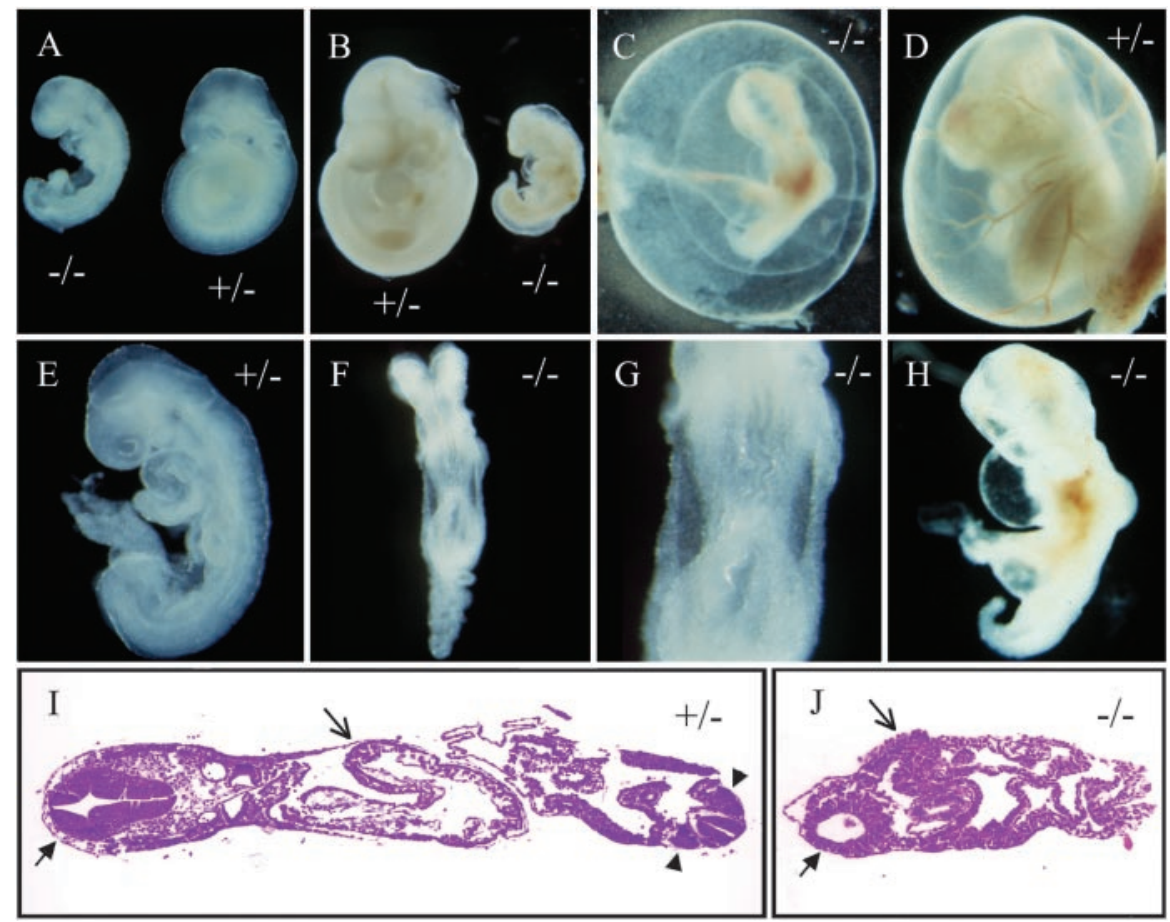

Figure 2. Phenotype of nicastrin mutant embryos. $N C T^{-/-}$embryos at $\mathrm{E} 9(A)$ and $\mathrm{E} 9.5(B)$ display severe growth retardation and abnormal somite segmentation compared with $\mathrm{NCT}^{+/-}$or $\mathrm{NCT}^{+/+}$embryos. E8 $\mathrm{NCT}^{-/-}$embryos show a twisted neural tube and no somite segmentation $(F, G)$, whereas the $E 8 N^{+/-}$or $N C T^{+/+}$embryos show clear somite segmentation $(E)$. Although the yolk sac vasculature is well formed in the E10 $N C T^{+/-}$embryo $(D)$, vascular morphogenesis is abnormal in the $N C T^{-1-}$ embryo (C). The $N C T^{-/-}$embryos also show an underdeveloped heart $(H)$. Transverse sections through E9.5 embryos show disorganization of the trunk and the ventral neural tube and small unlooped hearts in the $N C T^{-/-}$embryo $(J)$, whereas in the $N C T^{+/-}$embryo $(I)$, segmented somites and a well developed heart are observed (note that $/$ and $J$ are shown in different scales). Solid arrow, Neural tube; arrow, heart; arrowhead, somite.
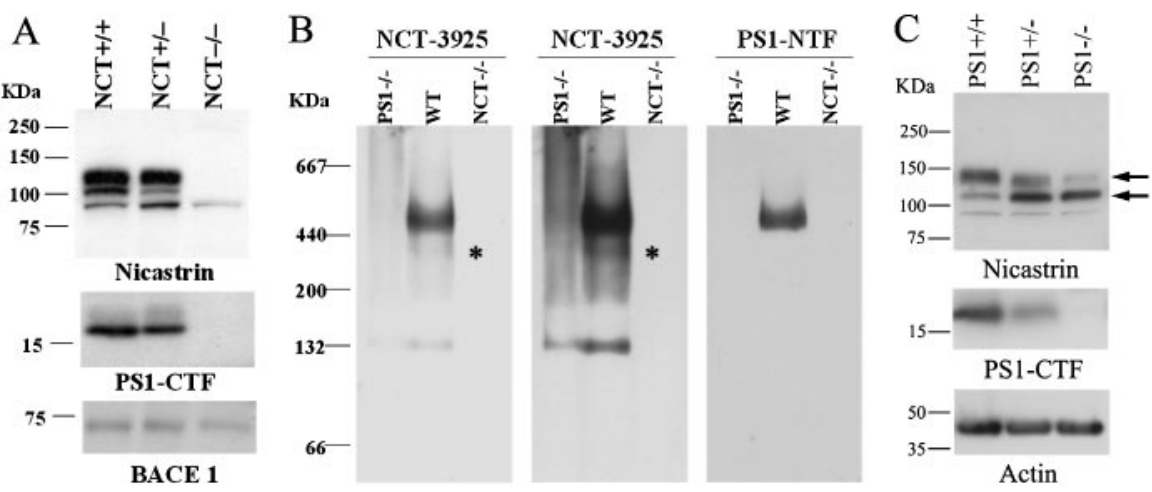

Figure 3. Nicastrin is required for assembly of PS1 into the $\gamma$-secretase complex. $A$, Cell lysates from NCT ${ }^{+/+}, N^{+/-}$, and $N C T^{-/-}$embryonic fibroblasts were immunoblotted using an antiserum specific for nicastrin and reprobed with antiserum against PS1-CTF or BACE1. Note that nicastrin and PS1 levels are markedly reduced in NCT ${ }^{+/-}$cells, whereas they are absent in $N C T^{-/-}$ fibroblasts. $B$, Lysates from membrane fractions of control, $P S 1^{-/-}$, and $N C T^{-/-}$cells were solubilized with DDM, subjected to BN-PAGE, and analyzed by immunoblotting using antibodies specific to either PS1-NTF or NCT. Note that cells deficient in PS1 or NCT fail to form a high molecular weight complex, and the asterisk denotes an apparent intermediate NCT-containing complex independent of PS1. The middle panel is a darker exposure of the left panel. WT, Wild type. $C$, Lysates of wild-type $\left(P S 1^{+/+}\right)$, $P S 1^{+/-}$, and $P S 1^{-/-}$cells were immunoblotted using antisera specific for NCT. The same blot was reprobed with antisera specific for PS1 (PS1-loop) or actin. Note that the ratio of immature to mature NCT in $P S 1^{+/-}$and $P S 1^{-/-}$cells is markedly altered compared with that in control fibroblasts. PS1-CTF, PS1 C-terminal fragment.

defects in angiogenic vascular morphogenesis in the yolk sac (Fig. $2 E, F)$, kinks in the neural tube (Fig. $2 F, G$ ), and distention of the pericardial sac (Fig. $2 \mathrm{H}$ ). Histological analysis revealed patterning defects in the neural tube and heart (Fig. $2 I, J$ ). Because the defects observed in $\mathrm{NCT}^{-/-}$embryos essentially resemble that of the Notch $^{-/-}$or $\mathrm{PS}^{-/-}$embryos, our results establish that NCT 


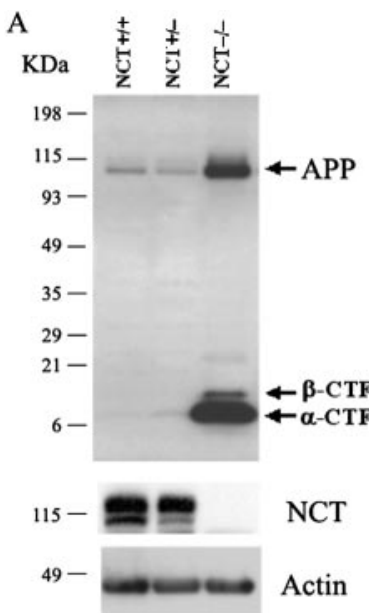

B

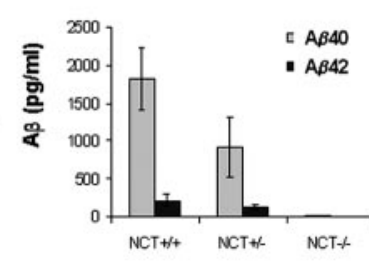

$\mathrm{C}$

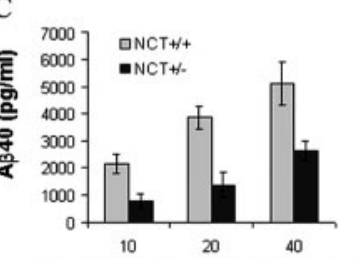

Amount of APP Adenovirus $(\mu \mathrm{l})$
D

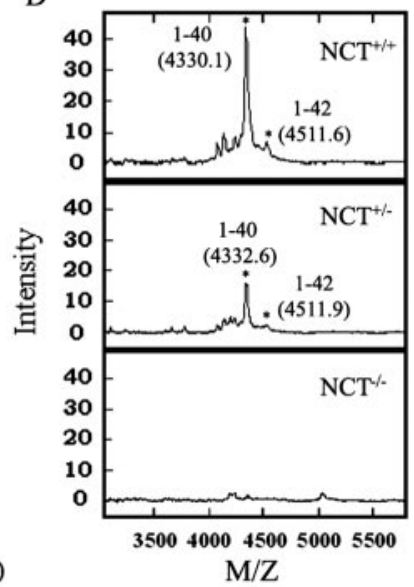

ined the level of PS1 in $\mathrm{NCT}^{-/-}$fibroblasts. Using an antibody that detects the C-terminal fragment of PS1 (Thinakaran et al., 1996), we observed that, whereas there are significant reductions of PS1 CTFs in $\mathrm{NCT}^{+/-}$cells compared with those of controls, PS1 CTFs are undetectable in $\mathrm{NCT}^{-/-}$fibroblasts (Fig. 3A). Moreover, formation of PS1 high molecular weight complexes are abolished in $\mathrm{NCT}^{-/-}$cells (Fig. $3 \mathrm{~B}$ ) as judged by blotting of blue native gel (Schagger and von Jagow, 1991) using an antibody against PS1 (Thinakaran et al., 1996). However, it is interesting to note that there appear to be nicastrin high molecular weight complexes devoid of PS1 (Fig. 3B), suggesting that nicastrin may initially form an intermediate complex with other members of the $\gamma$-secretase complex such as Aph-1 (anterior pharynx defective) or Pen-2 (presenilin enhancer) (Francis et al., 2002; Goutte et al., 2002; Lee et al., 2002; Steiner et al., 2002). Nevertheless, our results establish that nicastrin is required for the assembly of PS into the $\gamma$-secretase complex, consistent with the results observed
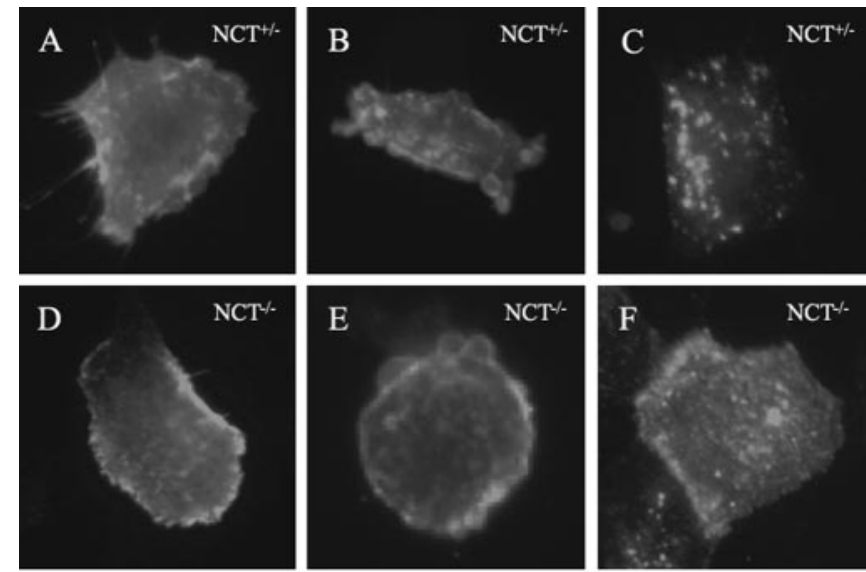

$0 \mathrm{~min}$

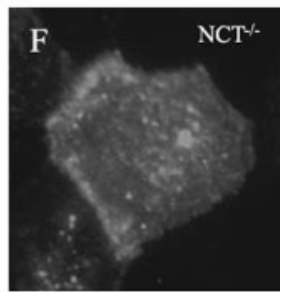

$15 \mathrm{~min}$
Figure 5. APP trafficking defects in $N C T^{-/-}$fibroblasts. Endocytosis of APP is delayed in $N C T^{-/-}$fibroblasts $(D-F)$ compared with $N C T^{+/+}$cells $(A-C) . N C T^{+/+}$and $N C T^{-/-}$cells were transiently expressing APPswe, labeled with antiserum P2-1, chased for 5 and 15 min at $37^{\circ} \mathrm{C}$, and fixed for immunofluorescence.

is required for Notch signaling and that NCT is necessary for both PS1- and PS2-dependent $\gamma$-secretase activities in mammals.

\section{Nicastrin is required for assembly of PS into $\gamma$-secretase complex}

To test the role of nicastrin in presenilin/ $\gamma$-secretase complex formation and APP processing, we established primary fibroblasts from E9.5 control, $\mathrm{NCT}^{+/-}$, and $\mathrm{NCT}^{-/-}$embryos. Protein-blotting analysis of fibroblast extracts with a highly specific NCT antiserum confirmed that NCT was undetectable in $N C T^{-/-}$fibroblasts, whereas in $\mathrm{NCT}^{+/-}$fibroblasts, NCT accumulated to $\sim 50 \%$ of the level of the $N C T^{+/+}$fibroblast, (Fig. $3 A$ ). Because initial studies in Drosophila (Hu et al., 2002) indicated that nicastrin might be required for stabilization of PS, we exam- using RNA interference (RNAi) approaches in insect and mammalian cells (Edbauer et al., 2002; Hu et al., 2002; Lopez-Schier and St Johnston, 2002). In addition, we have also confirmed that PS is necessary for the maturation and cell surface trafficking of nicastrin (Fig. 3C and data not shown), as demonstrated by several other groups (Edbauer et al., 2002; Leem et al., 2002).

APP processing and trafficking defects in $N C T^{-/-}$fibroblasts To examine the influences of nicastrin in APP processing and A $\beta$ secretion, we infected control, $\mathrm{NCT}^{+/-}$, and $\mathrm{NCT}^{-/-}$cells with recombinant adenovirus expressing a humanized APP cDNA bearing the Swedish variant (APPswe) (Cai et al., 2001). Protein blot analyses using CT15, an antibody specific for the $\mathrm{C}$ terminus of APP, revealed the accumulation of full-length APP and APPCTFs (Fig. $4 A$ ) in $N C T^{-/-}$cells, results that are reminiscent of those obtained in studies of PS1 or PS1+PS2 null cells (De Strooper et al., 1998; Naruse et al., 1998; Herreman et al., 2000; Zhang et al., 2000). Quantitative sandwich ELISA analyses from conditioned media of $N C T^{-/-}$cultures expressing APPswe showed undetectable levels of $\mathrm{A} \beta_{1-40}$ and $\mathrm{A} \beta_{1-42}$ (Fig. $4 \mathrm{~B}$ ); significantly, $\mathrm{A} \beta_{1-40}$ and $\mathrm{A} \beta_{1-42}$ peptides were markedly reduced in $\mathrm{NCT}^{+/-}$cells compared with controls (Fig. $4 \mathrm{~B}$ ). Additional analysis of $\mathrm{NCT}^{+/-}$cells infected with different amounts of APPexpressing adenovirus showed an $\sim 50 \%$ reduction of $\mathrm{A} \beta_{1-40}$ compared with that of control fibroblasts (Fig. 4C). Similarly, immunoprecipitation (IP)-MS analysis of conditioned culture media from control fibroblasts using an antiserum (6E10) specific to the $\mathrm{N}$ terminus of human $\mathrm{A} \beta$ revealed two prominent $\mathrm{A} \beta$ species with mass values corresponding to those of human $\mathrm{A} \beta_{1-40}$ and $\mathrm{A} \beta_{1-42}$, respectively (Fig. $4 D$, top panel). Importantly, secretion of these $\mathrm{A} \beta$ species is abolished from $N C T^{-/-}$ fibroblasts (Fig. $4 D$, bottom panel), whereas they are significantly reduced in $\mathrm{NCT}^{+/-}$cells (Fig. $4 \mathrm{D}$, middle panel). Together, these data establish that NCT is required for $\gamma$-secretase cleavage of APP-CTFs to release the A $\beta$ peptides and suggest that NCT is a potential therapeutic target for anti-amyloidogenic therapies. 
To confirm that the accumulation of APP in $\mathrm{NCT}^{-/-}$cells (Fig. 4A) might be caused by defects in APP reinternalization, we compared the rate of APP reinternalization in control and $N C T^{-/-}$fibroblasts. Labeling with $\mathrm{P} 2-1$, an antibody recognizing the ectodomain of APP, showed that the rate of APP reinternalization was markedly decreased in $\mathrm{NCT}^{-/-}$cells (Fig. 5D-F) compared with that of controls (Fig. $5 A-C$ ). These results indicate that the increased accumulation of APP in $\mathrm{NCT}^{-/-}$cells reflects defects in PS-dependent APP trafficking, an outcome consistent with the view that the nicastrin/PS complex facilitates the trafficking of APP (Kim et al., 2001; Kaether et al., 2002).

\section{Discussion}

Although initial studies in Caenorhabditis elegans and Drosophila established that nicastrin is critical for Notch signaling (Yu et al., 2000; Chung and Struhl, 2001; Hu et al., 2002; Lopez-Schier and St Johnston, 2002), it remained unresolved whether the deletion of nicastrin will lead to a complete or partial (Shen et al., 1997; Wong et al., 1997; De Strooper et al., 1998) Notch-null phenotype in mammals. Our results demonstrating that the phenotype of nicastrin knock-out mice (Fig. 2) resembles that of the Notch1-null (Swiatek et al., 1994; Conlon et al., 1995; Huppert et al., 2000) or PS-null (Donoviel et al., 1999; Herreman et al., 1999) embryos now establish that, in mammals, nicastrin is required for both PS1- and PS2-mediated Notch signaling during embryogenesis and that nicastrin is an essential component of the PS/ $\gamma$ secretase complex. Although studies in Drosophila using reporter constructs indicated that nicastrin is required for the processing of APP-CTFs (Chung and Struhl, 2001), it was not clear whether the secretion of $\mathrm{A} \beta$ was totally dependent on nicastrin. In addition, the finding of nicastrin RNAi studies showing an $\sim 70 \%$ reduction of $A \beta$ in mammalian cells (Edbauer et al., 2002) raised the possibility that $\mathrm{A} \beta$ secretion may not be completely dependent on nicastrin. However, the present investigation shows that fibroblasts deficient in nicastrin do not secrete $\mathrm{A} \beta$ peptides and accumulate high levels of APP-CTFs (Fig. 4), a result observed in studies of PS-null fibroblasts (Herreman et al., 2000; Zhang et al., $2000)$. This work established that nicastrin is required for the $\mathrm{PS} / \gamma$-secretase processing of APP and secretion of A $\beta$ peptides. Interestingly, our observations suggest that there is a nicastrin dose-dependent decrease of $\mathrm{A} \beta$ secretion from $\mathrm{NCT}^{+/-}$fibroblasts, a finding supporting the view that nicastrin is one limiting factor critical for the assembly of the PS/ $\gamma$-secretase complex (Thinakaran et al., 1996). It is encouraging that $N C T^{+/-}$mice show no overt pathology (up to 1.5 years of age) or obvious clinical phenotype (data not shown) in the face of marked reduction in secretion of $\mathrm{A} \beta$ from $N C T^{+/-}$fibroblasts. These results suggest that nicastrin may be a valuable anti-A $\beta$ drug target, and studies to test whether the decrease in nicastrin ameliorates $\mathrm{A} \beta$ deposition in transgenic mouse models of $\mathrm{AD}$ should be instructive.

Although recent cell culture studies from several laboratories as well as our present work have established that nicastrin is required for the stability of PS (Edbauer et al., 2002; Francis et al., 2002; Hu et al., 2002), the mechanisms whereby nicastrin facilitates stability or assembly of PS into a functional $\gamma$-secretase complex remain poorly understood. Whether nicastrin facilitates PS assembly through a direct interaction between nicastrin and PS remains to be established; however, the recent identification of Aph-1 and Pen-2 as critical components of the $\gamma$-secretase complex (Francis et al., 2002; Goutte et al., 2002; Lee et al., 2002; Steiner et al., 2002) raises the possibility that nicastrin may be acting through these or other as-yet-unidentified members. The findings that nicastrin, Aph-1, and Pen-2 are required for PS stability and that these components along with PS are localized to high molecular weight complexes are consistent with the view that these components are assembled into the mature active $\gamma$-secretase complex. It is interesting to note that there appear to be intermediate nicastrin-containing complexes that are independent of PS (Fig. 3). Whether these intermediate complexes are composed of Aph-1 or Pen-2 remains to be determined. Whether nicastrin, PS, Aph-1, and Pen-2 are sufficient for the formation of functional $\gamma$-secretase complexes remains to be established, and future investigations using our nicastrin-null cells should facilitate additional clarification of the mechanism of complex assembly.

Although the functional roles of PS remain incompletely elucidated, recent findings showing that PSs are targeted in a complex with nicastrin to the plasma membrane (Kaether et al., 2002) support dual roles for PSs in both $\gamma$-secretase processing (Wolfe et al., 1999) and trafficking of APP (Kim et al., 2001) and nicastrin (Leem et al., 2002). Our demonstration that the reinternalization of cell surface APP is markedly delayed (Fig. 5) and coupled with very substantial increases in APP as well as APP-CTFs in nicastrin-deficient fibroblasts compared with that in control cells (Fig. 4) is consistent with the view that a functional nicastrin/PS complex is necessary not only for $\gamma$-secretase activity but also for facilitating the trafficking of APP. The observation that nicastrin binds to both full-length APP and APP-CTFs as well as to PS (Yu et al., 2000; Kimberly et al., 2002; Yang et al., 2002) is also consistent with the notion that the nicastrin/PS complex plays a pivotal role in the trafficking of substrates.

In summary, the present investigation establishes that, in mammals, nicastrin is an essential component of the PS $/ \gamma$ secretase complex required for processing of APP and Notch as well as for trafficking of APP. The discoveries that $\mathrm{NCT}^{+/-}$mice are viable and without an overt phenotype and that a partial decrease in nicastrin leads to a marked reduction in $\mathrm{A} \beta$ secretion suggest that nicastrin may be a valuable therapeutic target for $\mathrm{AD}$. This concept can be evaluated in transgenic mouse models of $\mathrm{A} \beta$ amyloidosis.

\section{References}

Cai H, Wang Y, McCarthy D, Wen H, Borchelt DR, Price DL, Wong PC (2001) BACE1 is the major $\beta$-secretase for generation of $\mathrm{A} \beta$ peptides by neurons. Nat Neurosci 4:233-234.

Chen F, Yu G, Arawaka S, Nishimura M, Kawarai T, Yu H, Tandon A, Supala A, Song YQ, Rogaeva E, Milman P, Sato C, Yu C, Janus C, Lee J, Song L, Zhang L, Fraser PE, George-Hyslop PH (2001) Nicastrin binds to membrane-tethered Notch. Nat Cell Biol 3:751-754.

Chung HM, Struhl G (2001) Nicastrin is required for presenilin-mediated transmembrane cleavage in Drosophila. Nat Cell Biol 3:1129-1132.

Conlon RA, Reaume AG, Rossant J (1995) Notch1 is required for the coordinate segmentation of somites. Development 121:1533-1545.

De Strooper B, Saftig P, Craessaerts K, Vanderstichele H, Guhde G, Annaert W, Von Figura K, Van Leuven F (1998) Deficiency of presenilin-1 inhibits the normal cleavage of amyloid precursor protein. Nature 391:387-390.

De Strooper B, Annaert W, Cupers P, Saftig P, Craessaerts K, Mumm JS, Schroeter EH, Schrijvers V, Wolfe MS, Ray WJ, Goate A, Kopan R (1999) A presenilin-1-dependent $\gamma$-secretase-like protease mediates release of Notch intracellular domain. Nature 398:518-522.

Donoviel DB, Hadjantonakis AK, Ikeda M, Zheng H, Hyslop PS, Bernstein A (1999) Mice lacking both presenilin genes exhibit early embryonic patterning defects. Genes Dev 13:2801-2810.

Edbauer D, Winkler E, Haass C, Steiner H (2002) Presenilin and nicastrin regulate each other and determine amyloid $\beta$-peptide production via complex formation. Proc Natl Acad Sci USA 99:8666-8671.

Esler WP, Kimberly WT, Ostaszewski BL, Diehl TS, Moore CL, Tsai JY, Rah- 
mati T, Xia W, Selkoe DJ, Wolfe MS (2000) Transition-state analogue inhibitors of $\gamma$-secretase bind directly to presenilin-1. Nat Cell Biol 2:428-434.

Francis R, McGrath G, Zhang J, Ruddy DA, Sym M, Apfeld J, Nicoll M, Maxwell M, Hai B, Ellis MC, Parks AL, Xu W, Li J, Gurney M, Myers RL, Himes CS, Hiebsch R, Ruble C, Nye JS, Curtis D (2002) aph-1 and pen-2 are required for Notch pathway signaling, $\gamma$-secretase cleavage of $\beta$ APP, and presenilin protein accumulation. Dev Cell 3:85-97.

Goutte C, Tsunozaki M, Hale VA, Priess JR (2002) APH-1 is a multipass membrane protein essential for the Notch signaling pathway in Caenorhabditis elegans embryos. Proc Natl Acad Sci USA 99:775-779.

Hardy J, Selkoe DJ (2002) The amyloid hypothesis of Alzheimer's disease: progress and problems on the road to therapeutics. Science 297:353-356.

Herreman A, Hartmann D, Annaert W, Saftig P, Craessaerts K, Serneels L, Umans L, Schrijvers V, Checler F, Vanderstichele H, Baekelandt V, Dressel R, Cupers P, Huylebroeck D, Zwijsen A, Van Leuven F, De Strooper B (1999) Presenilin 2 deficiency causes a mild pulmonary phenotype and no changes in amyloid precursor protein processing but enhances the embryonic lethal phenotype of presenilin 1 deficiency. Proc Natl Acad Sci USA 96:11872-11877.

Herreman A, Serneels L, Annaert W, Collen D, Schoonjans L, De Strooper B (2000) Total inactivation of $\gamma$-secretase activity in presenilin-deficient embryonic stem cells. Nat Cell Biol 2:461-462.

$\mathrm{Hu}$ Y, Ye Y, Fortini ME (2002) Nicastrin is required for $\gamma$-secretase cleavage of the Drosophila Notch receptor. Dev Cell 2:69-78.

Huppert SS, Le A, Schroeter EH, Mumm JS, Saxena MT, Milner LA, Kopan R (2000) Embryonic lethality in mice homozygous for a processingdeficient allele of Notch1. Nature 405:966-970.

Kaether C, Lammich S, Edbauer D, Ertl M, Rietdorf J, Capell A, Steiner H, Haass C (2002) Presenilin-1 affects trafficking and processing of $\beta$ APP and is targeted in a complex with nicastrin to the plasma membrane. J Cell Biol 158:551-561.

Kim SH, Leem JY, Lah JJ, Slunt HH, Levey AI, Thinakaran G, Sisodia SS (2001) Multiple effects of aspartate mutant presenilin 1 on the processing and trafficking of amyloid precursor protein. J Cell Biol 277:43343-43350.

Kimberly WT, LaVoie MJ, Ostaszewski BL, Ye W, Wolfe MS, Selkoe DJ (2002) Complex N-linked glycosylated nicastrin associates with active $\gamma$-secretase and undergoes tight cellular regulation. J Biol Chem 277:35113-35117.

Lee SF, Shah S, Li H, Yu C, Han W, Yu G (2002) Mammalian APH-1 interacts with presenilin and nicastrin and is required for intramembrane proteolysis of amyloid- $\beta$ precursor protein and Notch. J Biol Chem 277:45013-45019.

Leem JY, Vijayan S, Han P, Cai D, Machura M, Lopes KO, Veselits ML, Xu H, Thinakaran G (2002) Presenilin 1 is required for maturation and cell surface accumulation of nicastrin. J Biol Chem 277:19236-19240.

Li YM, Lai MT, Xu M, Huang Q, DiMuzio-Mower J, Sardana MK, Shi XP, Yin KC, Shafer JA, Gardell SJ (2000a) Presenilin 1 is linked with $\gamma$-secretase activity in the detergent solubilized state. Proc Natl Acad Sci USA 97:6138-6143.

Li YM, Xu M, Lai MT, Huang Q, Castro JL, DiMuzio-Mower J, Harrison T, Lellis C, Nadin A, Neduvelil JG, Register RB, Sardana MK, Shearman MS, Smith AL, Shi XP, Yin KC, Shafer JA, Gardell SJ (2000b) Photoactivated $\gamma$-secretase inhibitors directed to the active site covalently label presenilin 1. Nature 405:689-694.

Lopez-Schier H, St Johnston D (2002) Drosophila nicastrin is essential for the intramembranous cleavage of Notch. Dev Cell 2:79-89.

Marambaud P, Shioi J, Serban G, Georgakopoulos A, Sarner S, Nagy V, Baki
L, Wen P, Efthimiopoulos S, Shao Z, Wisniewski T, Robakis NK (2002) A presenilin-1/ $\gamma$-secretase cleavage releases the E-cadherin intracellular domain and regulates disassembly of adherens junctions. EMBO 21:1948-1956.

Naruse S, Thinakaran G, Luo JJ, Kusiak JW, Tomita T, Iwatsubo T, Qian X, Ginty DD, Price DL, Borchelt DR, Wong PC, Sisodia SS (1998) Effects of PS1 deficiency on membrane protein trafficking in neurons. Neuron 21:1213-1221.

Ni CY, Murphy MP, Golde TE, Carpenter G (2001) $\gamma$-Secretase cleavage and nuclear localization of ErbB-4 receptor tyrosine kinase. Science 294:2179-2181.

Price DL, Sisodia SS (1998) Mutant genes in familial Alzheimer's disease and transgenic models. Annu Rev Neurosci 21:479-505.

Saxena MT, Schroeter EH, Mumm JS, Kopan R (2001) Murine Notch homologs (N1-4) undergo presenilin-dependent proteolysis. J Biol Chem 276:40268-40273.

Schagger H, von Jagow G (1991) Blue native electrophoresis for isolation of membrane protein complexes in enzymatically active form. Anal Biochem 199:223-231.

Shen J, Bronson RT, Chen DF, Xia W, Selkoe DJ, Tonegawa S (1997) Skeletal and CNS defects in presenilin-1-deficient mice. Cell 89:629-639.

Sisodia SS, George-Hyslop PH (2002) $\gamma$-Secretase, Notch, A $\beta$ and Alzheimer's disease: where do the presenilins fit in? Nat Rev Neurosci 3:281-290.

Steiner H, Winkler E, Edbauer D, Prokop S, Basset G, Yamasaki A, Kostka M, Haass C (2002) PEN-2 is an integral component of the $\gamma$-secretase complex required for coordinated expression of presenilin and nicastrin. J Biol Chem 277:39062-39065.

Swiatek PJ, Lindsell CE, del Amo FF, Weinmaster G, Gridley T (1994) Notch1 is essential for postimplantation development in mice. Genes Dev 8:707-719.

Thinakaran G, Borchelt DR, Lee MK, Slunt HH, Spitzer L, Kim G, Ratovitsky T, Davenport F, Nordstedt C, Seeger M, Hardy J, Levey AI, Gandy SE Jenkins NA, Copeland NG, Price DL, Sisodia SS (1996) Endoproteolysis of presenilin 1 and accumulation of processed derivatives in vivo. Neuron 17:181-190

Wolfe MS, Xia W, Ostaszewski BL, Diehl TS, Kimberly WT, Selkoe DJ (1999) Two transmembrane aspartates in presenilin-1 required for presenilin endoproteolysis and $\gamma$-secretase activity. Nature 398:513-517.

Wong PC, Zheng H, Chen H, Becher MW, Sirinathsinghji DJ, Trumbauer ME, Chen HY, Price DL, Van der Ploeg LH, Sisodia SS (1997) Presenilin 1 is required for Notch 1 and DII1 expression in the paraxial mesoderm. Nature 387:288-292.

Wong PC, Cai H, Borchelt DR, Price DL (2002) Genetically engineered mouse models of neurodegenerative diseases. Nat Neurosci 5:633-639.

Yang DS, Tandon A, Chen F, Yu G, Yu H, Arawaka S, Hasegawa H, Duthie M Schmidt SD, Ramabhadran TV, Nixon RA, Mathews PM, Gandy SE Mount HT, George-Hyslop P, Fraser PE (2002) Mature glycosylation and trafficking of nicastrin modulate its binding to presenilins. J Biol Chem 277:28135-28142.

Yu G, Nishimura M, Arawaka S, Levitan D, Zhang L, Tandon A, Song YQ Rogaeva E, Chen F, Kawarai T, Supala A, Levesque L, Yu H, Yang DS Holmes E, Milman P, Liang Y, Zhang DM, Xu DH, Sato C, et al. (2000) Nicastrin modulates presenilin-mediated notch/glp-1 signal transduction and $\beta A P P$ processing. Nature 407:48-54.

Zhang Z, Nadeau P, Song W, Donoviel D, Yuan M, Bernstein A, Yankner BA (2000) Presenilins are required for $\gamma$-secretase cleavage of $\beta$-APP and transmembrane cleavage of Notch-1. Nat Cell Biol 2:463-465. 